\title{
Books also Received
}

\author{
Received 1 January 2016-7 April 2016
}

Susan E. Cayleff, Nature's Path: A History of Naturopathic Healing in America (Baltimore, MD: Johns Hopkins University Press, 2016), pp. 408, \$39.95, hardback, ISBN: 978-1-4214-1903-9.

Luba Vikhanski, Immunity: How Elie Metchnikoff Changed the Course of Modern Medicine (Chicago, IL: Chicago Review Press, 2016), pp. 336, \$26.99, hardback, ISBN: 978-1-61373-110-9.

Georgia L. Irby-Massie (ed.), A Companion to Science, Technology, and Medicine in Ancient Greece and Rome, Vol. 2 (Chichester and Hoboken, NJ: Wiley-Blackwell, 2016), pp. 1120, \$325.00, hardback, ISBN: 978-1-118-37267-8.

Jaap Grave, Rick Honings and Bettina Noak (eds), Illness and Literature in the Low Countries: From the Middle Ages until the 21st Century (Göttingen: V\&R Unipress, 2016), pp. 278, €50.00, hardback, ISBN: 978-3-8471-0520-6.

Cristina Bellorini, The World of Plants in Renaissance Tuscany: Medicine and Botany (Farnham and Burlington, VT: Ashgate, 2016), pp. 284, £95.00, hardback, ISBN: 978-14724-6622-8.

Martin Dinges, Kay Peter Jankrift, Sabine Schlegelmilch and Michael Stolberg (eds), Medical Practice, 1600-1900: Physicians and Their Patients (Leiden and Boston, MA: Brill, 2015), pp. xii + 359, €115.00, \$149.00, hardback, ISBN: 978-90-04-30329-4.

Stephen Coss, The Fever of 1721: The Epidemic That Revolutionized Medicine and American Politics (New York: Simon \& Schuster, 2016), pp. 368, \$28.00, hardback, ISBN: 978-1-4767-8308-6.

David Gentilcore, Food and Health in Early Modern Europe Diet, Medicine and Society, 1450-1800 (London and New York: Bloomsbury Academic, 2016), pp. 264, \$34.95, paperback, ISBN: 978-1-4725-3497-2.

Mark D. Hardt, History of Infectious Disease Pandemics in Urban Societies (Lanham, MD: Lexington Books, 2016), pp. 272, \$90.00, hardback, ISBN: 978-0-7391-8026-6.

Eva Brinkschulte, Fritz Dross, Anita Magowska, Marcin Moskalewicz and Philipp Teichfischer (eds), Medizin und Sprache: die Sprache der Medizin (Frankfurt am Main and New York: PL Academic Research, 2016), pp. 235, €46.70, £37.00, \$60.95, hardback, ISBN: 978-3-631-65596-2.

David Wright and Laurence Monnais, Doctors beyond Borders: The Transnational Migration of Physicians in the Twentieth Century (Toronto, Buffalo and London: University of Toronto Press, 2016), pp. 272, \$55.00, hardback, ISBN: 978-1-4426-2961-5.

Roger Cooter and Claudia Stein (eds), The History of Medicine, 4 volume set (Oxford and New York: Routledge, 2015), pp. 1650, £760.00, hardback, ISBN: 978-1-138-017184.

L. Kerr Dunn (ed.), Mysterious Medicine: The Doctor-Scientist Tales of Hawthorne and Poe (Kent, OH: Kent State University Press, 2016), pp. 288, \$35.00, paperback, ISBN: 978-1-60635-272-4. 
Sherry Sayed Gadelrab, Medicine and Morality in Egypt: Gender and Sexuality in the Nineteenth and Early Twentieth Centuries (London and New York: I. B. Tauris, 2016), pp. 216, £64.00, \$99.00, hardback, ISBN: 978-1-78076-751-2.

Erika Dyck and Larry Stewart (eds), The Uses of Humans in Experiment: Perspectives from the 17th to the 20th Century (Leiden: Brill, 2016), pp. xii $+297, € 115.00, \$ 149.00$, hardback, ISBN: 978-90-04-28670-2.

Andrew Schonebaum, Novel Medicine: Healing, Literature, and Popular Knowledge in Early Modern China (Seattle, WA: University of Washington Press, 2016), pp. 296, \$50.00, hardback, ISBN: 978-0-295-99518-2.

Thomas M. Walshe, Neurological Concepts in Ancient Greek Medicine (New York and Oxford: Oxford University Press, 2016), pp. 224, \$55.00, £35.99, hardback, ISBN: 978-019-021856-0.

David G. Wittner and Philip C. Brown (eds), Science, Technology, and Medicine in the Modern Japanese Empire (Oxford and New York: Routledge, 2016), pp. 290, £90.00, hardback, ISBN: 978-1-138-90533-7.

Anna Winterbottom and Facil Tesfaye (eds), Histories of Medicine and Healing in the Indian Ocean World, Volume Two: The Modern Period (Basingstoke: Palgrave Macmillan, 2016), pp. xi + 282, \$95.00, hardback, ISBN: 978-1-137-56761-1.

Laurinda Abreu, The Political and Social Dynamics of Poverty, Poor Relief and Health Care in Early-Modern Portugal (Oxford and New York: Routledge, 2016), pp. 302, $£ 95.00$, hardback, ISBN: 978-1-4724-7725-5.

Simon Hofmann, Umstrittene Körperteile: Eine Geschichte der Organspende in der Schweiz (Bielefeld: Transcript Verlag, 2016), pp. 334, €37.99, paperback, ISBN: 9783-8376-3232-3.

Richard Whatmore and Brian Young (eds), A Companion to Intellectual History (Malden, MA: Wiley-Blackwell, 2015), pp. 472, \$195.00, hardback, ISBN: 978-1-11829480-2.

Juanita De Barros and Sean Arnold Stilwell (eds), Public Health and the Imperial Project (Trenton, NJ: Africa World Press, 2016), pp. 262, \$29.95, paperback, ISBN: 9781-592215-33-1.

Siegfried Weichlein and Linda Ratschiller (eds), Der schwarze Körper als Missionsgebiet: Medizin, Ethnologie, Theologie in Afrika und Europa 1880-1960 (Köln: Böhlau, 2015), pp. 189, €35.00, paperback, ISBN: 978-3-412-50166-2.

Isabelle Crommelynck, Petit dictionnaire de la médecine au théâtre: De Molière á nos jours (Paris: Hermann, 2016), pp. 324, €24.00, paperback, ISBN: 978-2-7056-9181-3.

Paul Mazliak, Jean Fernel: Premier physiologiste de la Renaissance (Paris: Hermann, 2016), pp. 164, €22.00, paperback, ISBN: 978-2-7056-9184-4.

Christian Krötzl, Katariina Mustakallio and Jenni Kuuliala (eds), Infirmity in Antiquity and the Middle Ages: Social and Cultural Approaches to Health, Weakness and Care (Oxford and New York: Routledge, 2016), pp. 334, £75.00, hardback, ISBN: 978-1-4724-3834-8. 
Christian Laes, Katariina Mustakallio and Ville Vuolanto (eds), Children and Family in Late Antiquity: Life, Death and Interaction (Leuven: Peeters, 2015), pp. xvi + 374, $€ 72.00$, paperback, ISBN: 978-90-429-3135-0.

Martin Dinges and Andreas Weigl (eds), Gender-Specific Life Expectancy in Europe 1850-2010 (Stuttgart: Franz Steiner Verlag, 2016), pp. 217, €44.00, paperback, ISBN: 978-3-515-11258-1.

Jenny Linek, Gesundheitsvorsorge in der DDR zwischen Propaganda und Praxis (Stuttgart: Franz Steiner Verlag, 2016), pp. 242, €46.00, paperback, ISBN: 978-3-51511281-9.

Compiled by Okumura Daisuke, University of Tokyo. 